\title{
5
}

\section{Wanted: A Revolution in Agriculture}

\begin{abstract}
Agriculture is the backbone of many African economies. Cilliers explores the history and role of agriculture in development, and the likely future trajectory of agriculture in Africa along the Current Path, drawing lessons from other regions. Improvements in this sector, particularly access to finance and use of modern technology can unlock the significant potential to achieve food security, improve health and nutrition outcomes, create agribusiness ventures that influence employment, earn foreign exchange through exports and promote economic prosperity. The chapter concludes with a scenario that emulates the impact of a revolution in agriculture on food security and growth.
\end{abstract}

Keywords Yields · Productivity · Calories · Food security · Agricultural efficiency $\cdot$ Intensive-farming $\cdot$ Poverty $\cdot$ Agriculture

\section{Learning objectives}

- Agriculture as foundational to human development and industrialisation

- Constraints on agricultural development in Africa

- Importance of food self-sufficiency for sustainable development.

Agriculture is the bedrock of human development-in many ways, farming is the organising principle of civilisation. The clustering of societies alongside the great rivers of the world from the Nile and the Euphrates to the Yangtze would not have been possible without the domestication of animals and the cultivation of crops that allowed for denser concentrations 
of people. This historical occurrence, the Neolithic revolution, started more than 12,000 years ago when the pressure of rising numbers and changing climates forced humans to adapt from their nomadic hunter-gatherer lifestyle and slowly turned to farming to meet the needs of their growing populations.

The Neolithic revolution led to food being stored in granaries and the domestication of animals for slaughter, transport and work. It also brought new infectious diseases, such as tuberculosis, smallpox and measles due to the concentration of people in permanent settlements. While this greater concentration of people did little to improve the quality of life for many, it was key to development.

Previously hunter-gatherer societies were constantly on the move in search of food. Farmers, on the other hand, needed to remain close to their fields and could store food surpluses for winter or to feed more animals. They generally had more children, in part as a source of labour but also because many died. With the transition to farming, humanity became sedentary in settled villages and towns with specialised food-crop cultivation, irrigation and close to cleared areas for tilling and planting. They made pots to preserve foods and developed ways of storing knowledge (writing). Soon a division of labour followed and communities started a barter system of trade, developed rules of property ownership and learnt how to use metal.

With the noteworthy exceptions of the Nile river, modern-day Ethiopia and some parts of West Africa and the Sahel, the agricultural development pathway in Africa followed a somewhat unique trajectory. The low population density was partly a function of Africa's high disease burden (examined in Chapter 3). Because much of Africa is located in the tropics with relatively high and stable temperatures and little seasonal change there is little relief from the activities of harmful bacteria or disease-bearing insects and mammals such as mosquitoes and bats. The subsequent high disease burden kept population levels down in large parts of the continent even as humanity expanded rapidly elsewhere.

In addition poor soil quality also seems to have played a role in constraining agricultural development in Africa. The overall availability of nutrients in soil is initially determined by the nature of the geological parent material, which in the continent's more ancient soils are poor. The most significant exception is along great rivers such as the Nile and along the length of the Great Rift Valley in East and Central Africa. ${ }^{1}$

${ }^{1}$ Reader, J., 1998. Africa: A Biography of the Continent. New York: Penguin Books, p. 99. Also see Diamond, J., 2015. Guns, Germs and Steel: The Fates of Human Societies. New York City: W. W. Norton. Also Tignor, R., Adelman, J., Brown, P., Elman, B., Liu, X., Pittman, H., and Shaw., B., 2010. Worlds Together, Worlds Apart: A History of the World: Beginnings Through the Fifteenth Century. 3rd Edition ed. New York: W. W. Norton. A 1997 study by the US Department of Agriculture 
For these and other reasons, farming seems to have emerged in sub-Saharan Africa much later than elsewhere, although our evidence on exactly how and why this happened continues to evolve. Another reason could relate to the relative short lifespan of Africa's numerous empires, which all collapsed or were forcibly dismantled by outsiders before organised agriculture could establish itself and spread. ${ }^{2}$

In more recent history, slavery, particularly the Arab slave trade in North and East Africa in the mid-seventh century and the European slave trade from late fifteenth century, disrupted agricultural development. From the sixteenth to the nineteenth-century slave trade in North and East Africa overlapped with the Transatlantic slave trade. Collectively the two had a devastating impact on the African continent. While the ten centuries of the Arab slave trade was more of a steady trickle rather than a deluge, the size of the Arab slave trade was at least equal to if not larger than the 10-12 million Africans that were forcibly captured and shipped to the Americas. ${ }^{3}$ Slavery meant that African societies remained more dispersed and mobile than others.

In a situation of lawlessness and violence where large populations were constantly on the move to avoid capture, farming was challenging. Once potential slaves had been captured it was often the young, elderly or disabled who were left behind. In the process large parts of Africa were denuded of its productive labour force. Farming and herding could therefore not develop in a systematic manner and neither could social, political and economic systems mature to allow for technological and productivity improvements to track development in other regions of the world. ${ }^{4}$

With the demise of slave trade at the beginning of the nineteenth century following abolishment in Britain in 1807 and the USA in 1865, the continuous drain of labour ended. However, it was soon replaced by other forced labour schemes under the guise of imperialism and colonialism.

During the Berlin conference in 1884 Africa was divided between various European states. In the decades that followed the continent became an increasingly important source of raw materials such as cotton to feed the factories in Great Britain, Germany, Belgium, France, Italy, Portugal and

\footnotetext{
calculates that 'Fifty five percent of the land in Africa is unsuitable for any kind of agriculture except nomadic grazing.' Eswaran, H., Almaraz, R., Reich, P., and Zdruli, P., 1997. Soil Quality and Soil Productivity in Africa. Journal of Sustainable Agriculture, 10(4).

${ }^{2}$ Aydon, C., 2009. A Brief History of Mankind: An Introduction to 150,000 Years of Human History. Philadelphia: Running Press; Diamond, J., 2015. Guns, Germs and Steel: The fates of human societies. New York City: W.W. Norton; Reader, J., 1998. Africa: A Biography of the Continent. New York: Penguin Books.

${ }^{3}$ Shahadah, A., 2017. Arab Slave Trade. [Online] Available at: http://www.arabslavetrade.com/.

${ }^{4}$ Lewis, T., 2018. Transatlantic Slave Trade. [Online] Available at: https://www.britannica.com/topic/ transatlantic-slave-trade.
} 
Spain, linking and shaping Africa's agricultural exports to the demands of its colonisers. Exports had to be supplied at the lowest possible price and since labour costs were the most important cost consideration, it comes as no surprise that Africans generally received poverty wages at the sprawling colonial farms on which they worked.

Elsewhere the introduction of crops such as peanuts and sesame replaced dietary staples such as millet and sorghum. The result was declining food reserves, chronic malnutrition and famine in spite of the development of a sizable commercial cash crop system that was, in turn, dominated by settler farmers.

With a firm focus on exports to feed and industrialise its colonial masters, Africa's infrastructure of road and rail was orientated towards the coast from where its produce could be shipped to Europe. Consequently, the rural and domestic agricultural sector and regional trade were either destroyed or remained economically marginal. In this way slavery, imperialism and colonialism fundamentally altered the development of agriculture on the continent. It effectively destroyed Africa's burgeoning trade in food and displaced a host of indigenous crops with foodstuffs and commodities that were useful for the industrialising economies in Europe but that undermined food security at home.

Effectively, Africa was forced to export more commodities whose values were declining as the terms of trade, i.e. the ratio between export prices versus import prices for non-oil primary commodities, steadily declined over the long term. According to one estimate Africa's terms of trade in $1940 \mathrm{had}$ reverted to the levels it experienced in 1800 as the continent became poorer compared to all other regions. ${ }^{5}$

\section{After Independence}

Independence brought many benefits, but few accrued to agriculture for, with limited exceptions, Africa's post-independent leaders placed rural and agricultural development at the very end of the line in terms of resource and budgetary allocation. Locked into an inequitable supply chain that effectively penalised efforts towards food self-sufficiency and disincentivised improvement of domestic value-add to its agricultural commodities, Africa's agricultural productivity continued to lag further and further behind other regions.

${ }^{5}$ Frankema, E., 2015. How Africa's Colonial History Affects Its Development. [Online] Available at: https://www.weforum.org/agenda/2015/07/how-africas-colonial-history-affects-its-development/. 
In September 1973 World Bank president Robert McNamara, in an oftcited speech delivered to his Board of Governors in Nairobi, clearly identified the root of Africa's major problem of rural poverty as the lack of smallholder agricultural development. ${ }^{6}$

McNamara's speech came at a time of relative growth in Africa although more than 200 million Africans lived in absolute poverty (with many more in Asia). He pointed out that official development assistance was 'acutely inadequate' to respond to this situation while government debt was increasing in the most affected countries.

Under his leadership, the Bank aggressively pursued a strategy for rural development with an emphasis on productivity of smallholder agriculture. By the time that McNamara stepped down in 1981 the World Bank had significantly extended its efforts at agricultural development. ${ }^{7}$ However, the Bank's efforts were scaled down and dismantled after he left.

McNamara's resignation in 1981 after 13 years as president of the Bank coincided with a decline in Africa's fortunes as successive oil and other shocks took their toll. From 1980 to 1994 income per capita declined and only returned to its 1980 levels in 2004—although things were improving, Africa was falling further behind. ${ }^{8}$

\section{Agriculture Today}

According to the most recent (2017) UN Food and Agriculture Organization (FAO) data, 14 of the 20 countries with the lowest average cereal yields per hectare globally, were in Africa. ${ }^{9}$ At the same time Africa is home to only one of the top 10 most productive agricultural sectors in terms of cereal yields. That country is Egypt, which obviously benefits from having one of the most productive agricultural deltas in the world in the form of the Nile river.

\footnotetext{
${ }^{6}$ McNamara, R., 1973. Address to the Board of Governors by Robert S. McNamara Presidential speech. Washington, DC: World Bank.

${ }^{7}$ See Jochen Kraske with Becker, William H., Diamond, William, and Galambos, Louis, 1996. Bankers with a Mission: The Presidents of the World Bank, 1946-91. Oxford University Press, pp. 159-211.

${ }^{8}$ Rowen, H., 1980. McNamara to Step Down At World Bank Next Year. [Online] Available at: https:// www.washingtonpost.com/archive/politics/1980/06/10/mcnamara-to-step-down-at-world-bank-nextyear/a7f20b6b-f3cb-4661-9e10-a22a55eedc6a/?noredirect=on\&utm_term=.846cd4f3f97c.

${ }^{9}$ The data is taken from the World Bank, cereal yield (kg per hectare) https://data.worldbank. org/indicator/AG.YLD.CREL.KG?most_recent_value_desc=false\&view=chart. The African countries, in ascending order of productivity, are Cape Verde, Botswana, Niger, Algeria, Burkina Faso, Eswatini, Togo, Guinea, Senegal, Rwanda, Liberia, Comoros, Maurania and Burundi. The geographical spread of African countries highlights the scope of the problem.
} 


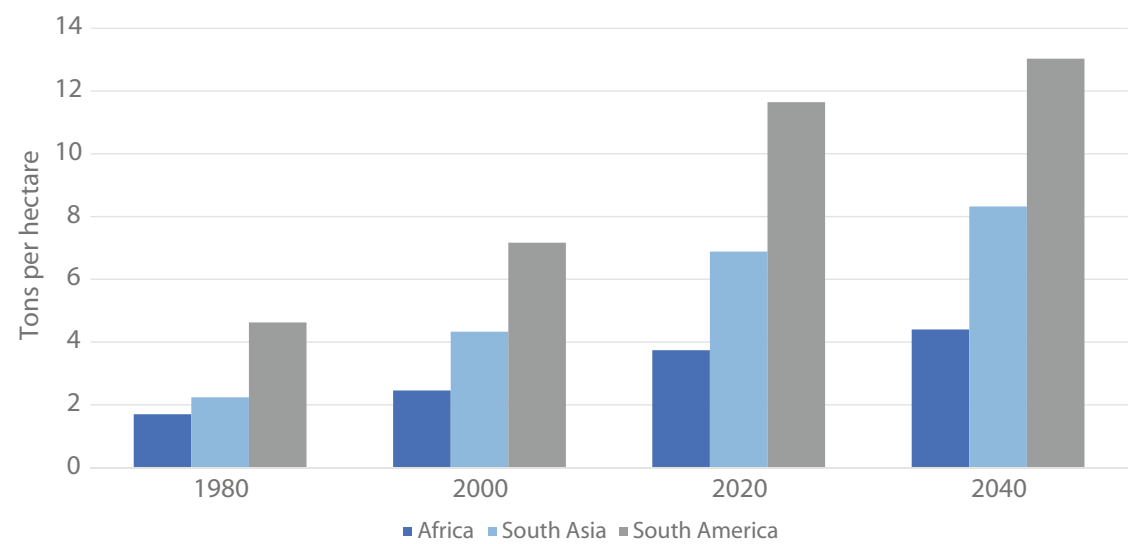

Fig. 5.1 Yields per hectare (pre-loss): 1980 and 2000, and Current Path forecast for 2020 and 2040 (Source Historical data from the Food and Agriculture Organization and forecast in IFs 7.45)

After Egypt, one has to scroll past 15 countries to find the next African state, South Africa, where agriculture contributes less than three percent to GDP.

Despite a few recent success stories like Ethiopia, Madagascar, Mauritania and Sierra Leone which doubled cereal yields between 2000 and 2016 the agricultural sector in sub-Saharan Africa is significantly less productive than in other regions. In 1980 agricultural yields in Africa were roughly similar to those in South Asia. But with crop yields at below four tons per hectare today, average agricultural yields in Africa are one-third of the average for South America (agriculturally one of the most productive regions globally) and three tons per hectare below that in South Asia. Figure 5.1 presents a snapshot of the growing gap in average yields between these three regions with historical data for 1980 and 2000 and the Current Path forecast for 2020 and 2040.

Furthermore, in Africa very little of the land under cultivation is irrigated. Globally, irrigated agriculture represents $21 \%$ of the total cultivated land, but contributes $40 \%$ to the total amount of food produced. Sub-Saharan Africa has the lowest portion of cultivated land under irrigation at just over three percent. ${ }^{10}$ This means that the vast majority of cropland is dependent on good rainfall which is increasingly irregular due to the impact of climate change.

\footnotetext{
${ }^{10}$ Food and Agriculture Organization, 2014. Aquastat Facts and Figures About. [Online] Available at: http://www.fao.org/nr/water/aquastat/didyouknow/index3.stm.
} 
Even though the agricultural yields per hectare on the continent is improving, it reflects a growing gap when compared to averages in the rest of the world, evident in Fig. 5.1. The pedestrian improvement in agriculture productivity in Africa amidst rapid population growth contributes to the slow rate of poverty reduction among other factors such as relatively high levels of inequality. Food security is declining as African countries import larger quantities of food with each passing year. ${ }^{11}$

In recent years Africa's annual agricultural trade deficit (the difference between the value of imports minus exports) stood at roughly US $\$ 100$ billion per annum and is expected to increase to more than US $\$ 330$ billion by 2030 . Along the Current Path forecast Africa could be importing more than a third of its agricultural requirements by 2040 , which leaves the continent extremely vulnerable to fluctuations in food and other commodity prices.

This import dependence is largely a result of low agricultural yields in much of Africa and large post-production losses, i.e. the loss and waste that occurs from production on the farm to consumption. Whereas the average loss and waste of agricultural produce in the rest of the world is roughly $14 \%$, in Africa it is calculated at 25\%. In West Africa it accumulates to more than $30 \%$. Unlike in Europe and North America where food reaches the consumer but is then discarded or wasted, most of the food loss in Africa happens in the production stage meaning that almost a third of the food being produced does not even reach the consumer. Better storage and infrastructure would help reduce losses, but more detailed data on the supply chain would also help—and here modern technology can play a large role.

The contribution of agriculture as a portion of an economy generally declines as countries graduate from low to middle and eventually to high-income status. For instance, in Africa's 24 low-income countries agriculture contributes an average of about $32 \%$ to GDP, about $22 \%$ in the 21 low-middle-income countries and about $8 \%$ in Africa's eight upper-middleincome countries. By 2040 these portions will have declined to 12, 9 and 6\%, respectively. Currently the agricultural sector in Western Africa is the largest (at US\$198 billion) and is expected to experience the most rapid growth since this is also the region where economies will expand most rapidly across the forecast horizon. By 2040 the size of West Africa's agricultural sector will have increased to US $\$ 238$ billion (or by $120 \%$ ). The agricultural sector in Central Africa is the smallest (currently at US\$33 billion) and although it too will grow (by 70\%) will only amount to US\$46 billion by 2040 . ${ }^{11}$ Veras, O., 2017. Agriculture in Africa: Potential Versus Reality. [Online] Available at: https://www.
howwemadeitinafrica.com/agriculture-africa-potential-versus-reality/57635/. 


\section{Obstacles to a Revolution in Agriculture}

According to the World Bank agricultural markets regularly fail African farmers. It notes in one of its reports that the 'pattern of market failures is general and structural, and not related to the head-of-household's gender, or to geographic characteristics such as distance to roads or to large population centers. ${ }^{12}$ In other words, African farms are less productive because farmers are chronically unable to access the finances (or credit) that would allow them to purchase critical inputs that could improve yields such as fertiliser and seed.

Take for example the matter of fertilisers. Generally the soil on the continent is poor in nutrients ${ }^{13}$ and since African farmers use significantly less fertiliser than their counterparts in other regions of the world, soil fertility depletion generally continues unabated. The reason for low fertiliser use is that prices in Africa are between two and six times the average world price because the continent generally imports fertiliser instead of manufacturing it. ${ }^{14}$ Then there is the issue of limited irrigation, low levels of mechanisation (since labour is cheap and farmers lack capital), lack of consensus and investment in genetically modified seeds that are more resilient to disease, slow progress with organic farming and the low use of indigenous crops that are better suited to the continent but that were largely phased out during colonialism.

African farmers have traditionally followed a practice of land rotation using slash and burn practices-they would clear new lands and leave the old field fallow for a year or two to recover. But as population numbers have increased, shortages of arable land have forced farmers to cultivate the same fields season after season. A lot of agricultural land is located in peri-urban areas (for instance in Kenya and Ethiopia) where urban sprawl is driving up land prices and swallowing up some of Africa's best farmland. These are often also the only areas with sufficient roads to allow the transport of produce to the market.

Elsewhere, where prime agricultural land is located far away from major population centres, the lack of paved roads and other infrastructure means

\footnotetext{
${ }^{12}$ World Bank, n.d. Agriculture in Africa: Telling Facts from Myths. [Online] Available at: http://www. worldbank.org/en/programs/africa-myths-and-facts.

${ }^{13}$ Hengl, T. Leenaars, J. G. B., Shepherd, K. D., Walsh, M. G., Heuvelink, G. B. M., Mamo. T., Tilahun, H., Berkhout, E., Cooper, M., Fegraus, E., Wheeler, I., and Kwabena, N. A., 2017. Soil Nutrient Maps of Sub-Saharan Africa: Assessment of Soil Nutrient Content at $250 \mathrm{~m}$ Spatial Resolution Using Machine Learning. Nutrient Cycling in Agroecosystems, 109(1), pp. 77-102.

${ }^{14}$ See, for example, Doukkali, M. R., and Guèdègbé, T. 2018, Fertilizer Use in Africa: A Price Issue, Policy Brief 18, OCP Policy Center, 29 August 2018, accessed on 23 December 2019. https://www. policycenter.ma/sites/default/files/OCPPC-PB1827-ENG.pdf.
} 
that arable land is effectively not used for large-scale production. The Democratic Republic of Congo and Angola are excellent examples of two countries with significant agricultural potential that have been wracked by conflict and the destruction of their limited infrastructure, hence constraining their ability to expand production.

Angola is one of Africa's largest and most fertile countries and was, before independence in 1975, self-sufficient in all main food crops except wheat. In fact it was the fourth largest coffee producer globally, but the subsequent war that lasted until 2002 destroyed much of its infrastructure. ${ }^{15}$ Most of its population fled to urban areas, generally to the capital Luanda. Today nearly seven out of ten Angolans reside in urban areas and it has a total road network that is in the region of 76,000 kilometres-only marginally better than the 72,300 kilometres that it had when it gained independence. ${ }^{16}$ And even these modest improvements followed a concerted recent effort by the government to invest in connecting infrastructure. Available data suggest that the extent of paved roads as a portion of total roads now stands at around $24 \%$ (it was around $10 \%$ before independence). ${ }^{17}$ As a result, in 2018, Angola ranked a poor 159th of 167 countries globally on the World Bank's Logistics Performance Index. Neighbouring Democratic Republic of Congo, host to the largest peacekeeping mission in the world and still wracked by instability in the east and elsewhere, is ranked at number $120 .^{18}$

Unsustainable cultivation practices in high-density areas are leading to serious soil degradation. ${ }^{19}$ What's more, as average farm sizes shrink, the pressure to get more food from less land in order to feed one's family tends to lead to unsustainable farming practices, which further decreases soil fertility. To this end the Alliance for a Green Revolution in Africa (AGRA) calls for a

\footnotetext{
${ }^{15}$ Food and Agriculture Organization, Angola Country Programming Framework, 2013-2017. www. fao.org/3/a-bp627e.pdf, p. 12; Nathan Associated Inc., 2006. Angola: Diagnostic Trade Integration Study. World Bank, p. 2.

${ }^{16}$ African Economic Outlook: Angola Country Note. African Development Bank, p. 9. www.afdb.org/ fileadmin/uploads/afdb/Documents/Generic-Documents/country_notes/Angola_country_note.pdf. See "Notes on road data" in the annexure for the sources of data.

${ }^{17}$ African Economic Outlook: Angola Country Note. African Development Bank, p. 9. www.afdb.org/ fileadmin/uploads/afdb/Documents/Generic-Documents/country_notes/Angola_country_note.pdf. See "Notes on road data" in the annexure for the sources of data.

${ }^{18}$ https://openknowledge.worldbank.org/bitstream/handle/10986/29971/LPI2018.pdf, p. 12.

${ }^{19}$ Fleshman, M., n.d. Boosting African Farm Yields. [Online] Available at: https://www.un.org/africaren ewal/magazine/special-edition-agriculture-2014/boosting-african-farm-yields. And AGRA, 2016. Africa Agriculture Status Report 2016: Progress Towards Agriculture Transformation in Sub-Saharan Africa. Nairobi: Africa Fertilizer and Agribusiness Partnership.
} 
holistic land management strategy that includes raising organic matter, moisture retention and other forms of soil rehabilitation in addition to greater inorganic fertiliser. ${ }^{20}$

Two findings from the literature on agriculture in Africa highlight its risks and dormant potential. Firstly, the World Bank notes that 'price risk is the most commonly reported covariate shock, much more so than weather shocks'. ${ }^{21}$ Price shocks can come in the form of increases in the cost of inputs like fertiliser and seeds, a collapse in output prices caused by a change in trade policy or just changes to the prices of other staple goods that influence people's ability to survive.

Secondly, farmers' inability to access credit and technology, combined with ineffective labour and input markets complicates matters. ${ }^{22}$ Very few farmers are able to purchase additional inputs credit and inevitably spend most of it on fertiliser. The result is that the vast majority of farmers count on bumper harvests to tide them over lean years to the next bumper harvest. These are few and far between and may become increasingly so as the impact of climate change is felt.

The result is that Africa is the most food insecure region globally. According to a joint communique issued by the World Bank, the Food and Agriculture Organization of the UN (FAO), the African Development Bank and the International Fund for Agricultural Development (IFAD) about 256 million Africans faced undernutrition in 2018. ${ }^{23}$ The situation is getting worse in many parts of the continent, the organisations stated, because of the negative effects of climate change on agricultural productivity, natural resource degradation, rapid population growth, increasing fragility and insecurity and economic stagnation.

\section{Achieving Food Security}

Traditionally, many countries in Africa have had large agricultural sectors but merely exported raw products without adding much, if any, value. For

\footnotetext{
${ }^{20}$ Jayne, T., and Ameyaw, D. S., 2016. Africa’s Emerging Agricultural Transformation: Evidence, Opportunities and Challenges. In: Africa Agriculture Status Report 2016: Progress Towards Agriculture Transformation in Sub-Saharan Africa. India: AGRA.

${ }^{21}$ World Bank, n.d. Droughts Dominate Africa's Risk Environment. [Online] Available at: http://www.worldbank.org/en/programs/africa-myths-and-facts/publication/droughts-dominate-afr icas-risk-environment.

${ }^{22}$ Alliance for a Green Revolution in Africa (AGRA), 2017. To Ensure Food Security, Keep Soils Healthy. https://agra.org/news/to-ensure-food-security-keep-soils-healthy/.

${ }^{23}$ Communique: Africa Food Security Leadership Dialogue, 5 August 2019. [Online] Available at: https://allafrica.com/view/resource/main/main/id/00121601.html.
} 
example, Africa produces $70 \%$ of the world's cocoa, the main ingredient in a chocolate industry that is worth more than US $\$ 100$ billion globally. Between the two of them Ghana and Côte d'Ivoire produce nearly two-thirds of the global supply of cocoa but Ghana only earns about US $\$ 2$ billion a year from its colonial-style arrangement with the world's chocolate manufacturers. In fact, Africa accounts for less than one percent of chocolate exports. Europe, which grows no cocoa of its own, exported US $\$ 19.2$ billion worth of chocolate in $2016 .^{24}$

After years of ineffective efforts at responding to the symptoms of this unequal relationship, such as well-meaning efforts to reduce widespread child labour, things have started to change. Through the Africa Cocoa Initiative, Côte d'Ivoire has overtaken the Netherlands as the world's largest processor of cocoa during the 2014-15 season as it moves up the chocolate value chain. And Ghana is now processing more than a third of its own cocoa. ${ }^{25}$ In an effort to increase the farm-gate prices to levels high enough to allow small cocoa producers to escape extreme poverty Ghana and Côte d'Ivoire unilaterally announced that, as from October 2020, they will be charging a fixed premium of US $\$ 400$ a ton over the benchmark futures price. ${ }^{26}$ The problem with such an approach, of course, is that it is likely to increase production and drive down the price, leaving the government to foot the difference. The policy is therefore unlikely to succeed without simultaneous management and control of domestic cocoa production.

But agricultural import dependence is not simply a balance of payments issue. It is also about calories. Hunger, malnutrition and low levels of educational attainment are all well-established causes and symptoms of Africa's underdevelopment and represent significant bottlenecks in the effort to build human capacity and bring about structural economic transformation. ${ }^{27}$

\footnotetext{
${ }^{24}$ Adegoke, Y., 2018. Why Europe Dominates the Global Chocolate Market While Africa Produces All the Cocoa. [Online] Available at: https://qz.com/africa/1320998/where-does-chocolate-come-from-eur ope-and-africas-roles-in-the-valuable-market/; Philling, D., 2019. The African Farmers Taking on Big Chocolate. The Financial Mail, 16 December 2019.

${ }^{25}$ Fofack, H., 2019. Overcoming the Colonial Development Model of Resource Extraction for Sustainable Development in Africa. [Online] Available at: https://www.brookings.edu/blog/africa-in-focus/2019/01/ 31/overcoming-the-colonial-development-model-of-resource-extraction-for-sustainable-developmentin-africa/.

26Philling, D., 2019. The African Farmers Taking on Big Chocolate. The Financial Mail, 16 December 2019.

${ }^{27}$ Stunting in particular reduces cognitive development and can negatively impact the productivity levels of those that are affected by it for their entire lives. Stunted children grow into stunted adults and if roughly $20 \%$ of a population suffers from this condition, as is currently the case in Africa, then it is going to be difficult-if not impossible- to promote the development of industries that require a healthy and reliable workforce.
} 
Between 1970 and 1990, Kenya was mostly a net exporter of food, exporting about one percent of total demand each year. But from 1997 to 2013 the country imported about five percent of total demand per year. The growing reliance on imported food in Kenya has coincided with a decrease in the number of available calories. In 1980, the average Kenyan had access to about 2300 calories per day, which is about equal to the recommended daily average. ${ }^{28}$ By 2000 , though, the average Kenyan could only expect to access about 2050 calories per day, about $11 \%$ less than the recommended allowance.

Insufficient access to calories is a driver of undernutrition and stunting and, together with a lack of access to improved WASH facilities, can lead to a variety of health problems leading to psychosocial and learning challenges (discussed in Chapter 3). ${ }^{29}$

To transition economies towards higher value-added activities, a healthy, well-educated population is a prerequisite. A lack of access to safe and affordable food can disrupt education and negatively affect other programmes aimed at improving long-run economic productivity.

In order to capitalise on the benefits of having an educated and healthy population there needs to be an unwavering emphasis on first achieving selfsufficiency, for research conducted by the World Bank finds 'little evidence of a relationship between increased commercialization and improved nutritional status. ${ }^{30}$

It is particularly imperative for low and low-middle-income African countries to first produce agricultural products for domestic consumption and only then to pursue cash crops for the export market. For example, Africa produces about $45 \%$ of the world's cashew nuts, with $90 \%$ of that crop being exported for processing overseas but with little obvious benefit to the 2.5 million farmers involved in the industry. The Africa Cashew Alliance estimates that a $25 \%$ increase in raw cashew nut processing in Africa would generate more than US\$100m household incomes in the sector. As it is, a recent report noted that Tanzania's farmers 'get rock bottom prices and the country imports its own nuts back after processing to meet buoyant domestic

\footnotetext{
${ }^{28}$ The recommended daily caloric intake will vary by individual but the British National Health Service recommends about 2500 calories a day for men and about 2000 for women. NHS, n.d. What Should My Daily Intake of Calories Be? [Online] Available at: https://www.nhs.uk/common-hea lth-questions/food-and-diet/what-should-my-daily-intake-of-calories-be/.

${ }^{29}$ Hughes, B. B., et al., 2011. Improving Global Health: Forecasting the Next 50 Years Is Third in the Patterns of Potential Human Progress. Volume 3 ed. Denver. Oxford: Paradigm.

${ }^{30}$ World Bank, n.d. Agriculture in Africa: Telling Facts from Myths. [Online] Available at: http://www. worldbank.org/en/programs/africa-myths-and-facts.
} 
demand'. ${ }^{31}$ Then, like with cocoa, efforts to increase prices for raw nuts could actually increase production resulting in reduced prices for both raw and processed nuts, hence defeating the purpose.

\section{The Challenge for the Future}

Talking about the importance of agriculture in Africa has been a serious business for several decades but actually doing something about it is taken much less seriously. The New Partnership for Africa's Development (NEPAD—now the African Union Development Agency-NEPAD) published its Comprehensive Africa Agriculture Development Programme (CAADP) in 2003 with ambitious goals:

... to allocate at least $10 \%$ of national budgets to agriculture, to reach rural growth rates of $6 \%$ annually by 2015 , integrate and invigorate regional and national agricultural markets, significantly increase agricultural exports, transform Africa into a "strategic player" in global agricultural science and technology, practice sound environmental and land management techniques, and reduce rural poverty. ${ }^{32}$

The commitment to devote at least $10 \%$ of national budgets to agriculture and rural development was included in the 2003 Maputo Declaration by African heads of state and government and reiterated in the 2014 Malabo Declaration on Accelerated Agricultural Growth and Transformation in Africa. But according to the Food and Agriculture Organization (FAO), only Malawi has achieved the $10 \%$ goal, and the average investment is around $2.5 \%$ of GDP and declining. ${ }^{33}$

Talk is cheap and many African governments, NGOs and citizens generally prefer to blame Europe for lack of access to its agricultural market instead of looking to the need to focus comprehensively on the production of staple foodstuffs for domestic consumption, advancing regional rather than international trade in agriculture, investing in agriculture research, advancing rural

\footnotetext{
${ }^{31}$ IPPMedia, 2019. Value Add in Africa: First Steps in a Long Journey. [Online] Available at: https:// www.ippmedia.com/en/business/value-add-africa-first-steps-long-journey Also see website of African Cashew Alliance. https://www.africancashewalliance.com/en/about-us.

${ }^{32}$ Fleshman, M., 2014. Boosting African Farm Yields. [Online] Available at: https://www.un. org/africarenewal/magazine/special-edition-agriculture-2014/boosting-african-farm-yields. NEPAD has subsequently been renamed to African Development Agency (ADA).

${ }^{33}$ Tignor, R., Adelman, J., Brown, P., Elman, B., Liu, X., Pittman, H., and Shaw, B., 2010. Worlds Together, Worlds Apart: A History of the World: Beginnings Through the Fifteenth Century. 3rd Edition. New York: W. W. Norton.
} 
property rights, in schooling for agriculture and generally focusing attention on rural poverty rather than on urban elites. ${ }^{34}$ If African countries prioritise growing staple foods while actively encouraging intensive smallholder farming and sustainable practices, it will increase rural incomes and reduce poverty and eventually open up the potential of agribusiness. This will lead to the much needed revolution in agriculture that will reduce Africa's agricultural import dependence and improve food security.

The potential advantages of agriculture are well known. Boosting the income of farmers' helps stimulate general demand for goods and services in rural areas, which result in new enterprises being established and the economy diversifying. This in turn contributes to the broader process of structural economic transformation. ${ }^{35}$ Improving agricultural productivity and boosting local demand 'leads to the development of both upstream and downstream activities, the consolidation of value chains and the expansion of agro-industries, which are significant sources of employment and present real opportunities for economic diversification', notes the International Labour Organization. ${ }^{36}$ That will remain true, even if most of the continent's intense agriculture often occurs in the periphery of urban centres, i.e. closer to the market, thanks to the denser network of roads and access to markets here, compared to low rural road density in Africa. The implication is that agricultural development is unlikely to detract from urban slum growth and may even exacerbate it. However, as Africa moves up the agricultural value chain, growth in this sector will expand employment opportunities further along that chain.

\section{Lessons from Elsewhere}

Africa is complex and its 55 countries are very different from one another and from other regions, but lessons can be learnt from elsewhere. Contrast, for example, the way in which Deng Xiaoping in China transformed the domestic agricultural sector into a much more productive market-oriented structure in the 1970s and 1980s through the household responsibility system. Land formerly farmed by a collective was henceforth contracted to individual households and, with this new responsibility and various other

\footnotetext{
${ }^{34}$ Food and Agriculture Organization, 2019. Government Expenditure on Agriculture. [Online] Available at: http://www.fao.org/economic/ess/investment/expenditure/en/.

${ }^{35}$ Losch, B., 2016. Structural Transformation to Boost Youth Labour Demand in Sub-Saharan Africa: The Role of Agriculture, Rural Areas and Territorial Development. Geneva: Employment Working Paper: No. 204. ILO.
}

36Ibid., p. 2. 
market-related reforms came productivity improvements to the order of $20 \%$ above collective era output. The basis for China's agricultural revolution, the first twenty years, was to focus first on improving productivity on smallholder farms through institutional incentivisation, improving access to better seeds and better farming practices. ${ }^{37}$

China subsequently experienced three consecutive decades of steady improvements in agricultural yields. Average yields nearly tripled between 1970 and 2013 and was an important catalyst in the economic growth enjoyed by the country during those decades. The number of available calories per person increased by nearly $70 \%$ and there were more than 20 million fewer undernourished children in 2017 than there were in 1987.

The African experience where small patches of land are owned or farmed by different families relying on unproductive, often traditional practices is quite similar to the situation in China several decades previously. By working from the individual farmer upward, by focusing on techniques and practices that improve smallholder productivity, China was able to transform its agricultural sector and feed its rapidly growing population. Today modern technology plays an important role in China (today copied in Rwanda) through numerous electronic land use transfer systems where farmers can lease their land out to others, creating larger and potentially more productive farms. ${ }^{38}$

China is not the only large and geographically diverse country to transform its agricultural sector in recent decades and from which Africa can learn. Brazil enjoyed rapid improvements in agricultural production in the decade between 2000 and 2010, and while it has traditionally been a net food exporter, the country has improved that position by nearly seven percentage points over that time period. Between 1981 and 2016 Brazil more than doubled average cereal yields despite the size of the land under cultivation only increasing by about $6 \%$.

Not only has Brazil's agricultural sector grown in absolute terms, it has also become very diverse, but like China only achieved that progress once it had graduated to an upper-middle-income country. Today Brazil is the world's largest exporter of both sugar and coffee, second only to the USA

\footnotetext{
${ }^{37}$ In contrast to the tripling in growth cited earlier, this was an improvement across the entire country, so is understandably much smaller. Lin, J. Y., 1988. The Household Responsibility System in China's Agricultural Reform: A Theoretical and Empirical Study. Economic Development and Cultural Change, 36(S3).

38The China-Africa project podcast no 437: Chinese and African Agriculture, Interview with Xinqing Lu, associate program officer for Alliance for a Green Revolution in Africa, 3 December 2019. https://chinaafricaproject.com/podcasts/chinese-and-african-agriculture-have-a-lot-more-in-com mon-than-most-people-think/, accessed on 25 December 2019.
} 
in soybean exports and third to the USA and Argentina in maize (corn) exports. ${ }^{39}$ The genetic tailoring of seeds and plants played an important role in these changes.

Brazil is now at a stage in development where it can afford to move beyond agricultural production for food security. The country exported approximately $12 \%$ more food than it consumed in 2018 and has begun to embrace a 'forest, agriculture and livestock integration' approach to farming that is widely acknowledged to have benefits for both agricultural production and environmental sustainability. ${ }^{40}$

At the other end of the spectrum is Zimbabwe-a country now with little food security. In 2005 former Zimbabwean President Robert Mugabe famously marked the occasion of Zimbabwe's 25th year of independence by saying 'we have turned East, where the sun rises and turn our back to the West, where the sun sets'. ${ }^{41}$ Like many of his speeches it was in defence of his disastrous land redistribution programme that eventually destroyed its most productive sector. Later his party would embark upon centralised 'command agriculture', which dealt a further blow to Zimbabwe's agricultural sector, once the breadbasket of Southern Africa. ${ }^{42}$

Between 1960 and 1990 Zimbabwe exported about ten percent more food than it consumed. By 2018 it was importing close to $26 \%$ of total demand.

\section{Modelling a Coordinated Push on Africa's Agricultural Sector: The African Agriculture Revolution Scenario}

A coordinated push on Africa's agricultural sector can unlock profound changes. This scenario, the African Agriculture Revolution, improves average yields in Africa from about 3.7 metric tons per hectare in 2018 to about 5.8

\footnotetext{
${ }^{39}$ Simoes A. J. G., and Hidalgo, C. A., 2011. The Economic Complexity Observatory: An Analytical Tool for Understanding the Dynamics of Economic Development. Workshops at the Twenty-Fifth AAAI Conference on Artificial Intelligence.

${ }^{40}$ Galford, G. L., Soares-Filho, B., and Cerri, C. E. P., 2013. Prospects for Land-Use Sustainability on the Agricultural Frontier of the Brazilian Amazon. Philosophical Transactions of the Royal Society B, 5 June.

${ }^{41}$ Meldrum, A., 2005. Mugabe Turns Back on West and Looks East. [Online] Available at: https://www. theguardian.com/world/2005/apr/19/zimbabwe.andrewmeldrum.

${ }^{42}$ It occurred as part of the 2016 Targeted Command Agriculture Programme, formally known as the Special Maize Import Substitution Programme. See Mazwi, F., Chemura, A., Mudimu, G. T., and Chambati, W., 2019. Political Economy of Command Agriculture in Zimbabwe: A State-led Contract Farming Model. Agrarian South: Journal of Political Economy, 8(1-2), pp. 232-257. https:// doi.org/10.1177/2277976019856742.
} 
tons per hectare in 2030 and 6.5 tons by 2040 . That would represent a 2040 increase of $180 \%$ compared to a mere $75 \%$ improvement expected along the Current Path. Latin America and the Caribbean achieved a much more rapid increase between 2000 and 2010, moving from roughly 6.9 tons per hectare to about 9.6 tons.

In addition to a direct increase in yields per hectare, the interventions within the IFs forecasting system that contribute to these impressive improvements consist of an increase in the area size of land used for crops (eventually by $17 \%$ above the Current Path in 2040) as well as a six percent increase in the portion of land under irrigation (above the 2040 Current Path forecast), and a reduction of seven percent in the loss and waste rate as expressed as a share of agricultural production by 2040 .

In addition the scenario increases the land area equipped for irrigation in Africa by almost a million hectares by 2040 (or by around seven percentage points).

The scenario also includes an increase in the number of available calories per person per day from about 2600 in 2018 to around 3100 in 2040, compared to a 2040 Current Path forecast of 2800 calories per person. This intervention is done to ensure that the increase in agricultural production does not only benefit exports, but improves domestic calorie consumption.

The impact of the African Agriculture Revolution scenario is impressive. By 2040, Africa will produce a total of 630 million tons of additional food (crop, meat and fish), i.e. above the Current Path forecast for 2040 of 1390 million metric tons of total agricultural production. With more domestic food being produced, the agricultural import bill is US $\$ 285$ billion lower in 2040 than it would otherwise have been the case. The increase in calories helps to reduce the number of children suffering from malnourishment by more than four million in 2040-a cumulative total, from 2020 to 2040, of almost eighty million less children suffering from malnourishment-and achieve a minor reduction in stunting. Finally, it reduces infant mortality by almost two children per 1000 live births under one year of age. In considering this, bear in mind that more than 43 million births occurred in Africa in 2018 and that the Current Path forecast is for almost 54 million to occur in 2040 !

Figure 5.2 presents a picture of Africa's growing food dependence over time, including demand for crops, meat and fish. In 2018, Africa already imports $13 \%$ of its agricultural demand, much of that consisting of staple foods such as rice and maize that is cheaper on the international market than can currently be produced domestically. Along the Current Path forecast that number will reach an alarming $35 \%$ by 2040 . The Revolution in Agriculture 


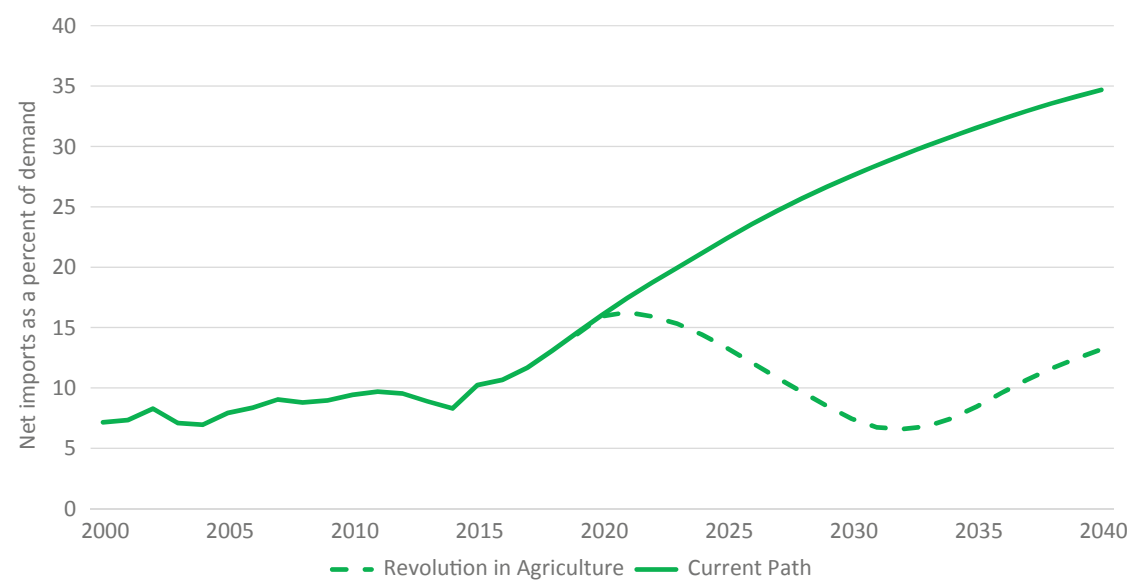

Fig. 5.2 Agricultural imports dependence: Current Path vs Revolution in Agriculture (Source Historical data from the Food and Agriculture Organization and forecast within IFs version 7.45)

reduces the continent's food insecurity dramatically to a situation, in 2040, where Africa will have reduced its forecast of import dependence to a much less alarming $13 \%$.

These averages conceal huge differences between countries and regions. Those countries that achieve the most spectacular increases in production volumes; Nigeria, Egypt, Ethiopia, the Democratic Republic of Congo and Tanzania, are well known for their agricultural potential while arid and small island states gain the least.

The African Agriculture Revolution scenario also has major economic impacts. It reduces the number of extremely poor Africans living below US $\$ 1.90$ by almost 130 million people in 2040. Gross domestic product (GDP) per person is in excess of US $\$ 310$ more in 2040. By 2040, Africa's total economy is almost US $\$ 460$ billion larger than it would otherwise be. ${ }^{43}$

Figure 5.3 presents the 2040 difference in the size of the agricultural sector between the Current Path and the Revolution in Agricultural scenario for each of the five regions used in this book. The difference in Central Africa is US\$21 billion, in Southern Africa it is US\$32 billion, in North Africa and East/Horn of Africa it is US\$74 billion each and in West Africa it is US\$109 billion. Currently the agricultural sector is the largest, as a percent of GDP in East/Horn of Africa (at 32\% of GDP) compared to only seven percent in Southern Africa.

${ }^{43}$ Numbers in MER except for GDP per capita, which is in PPP. 


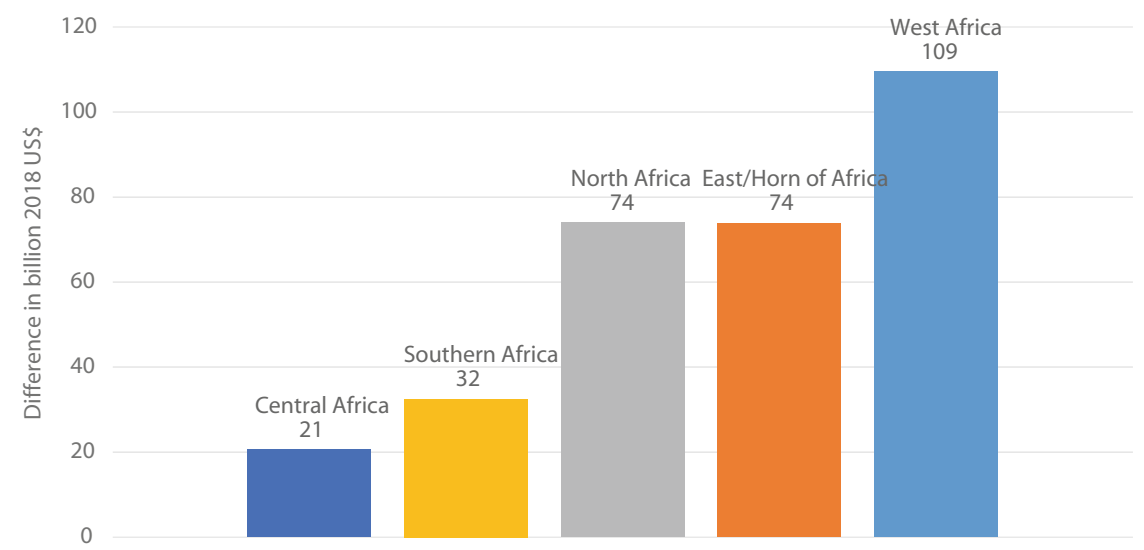

Fig. 5.3 Difference in size of agricultural sector in 2040: Revolution in Agriculture vs Current Path (Source Historical data from the Food and Agriculture Organization and forecast in IFs 7.45)

A different expression of the same metric is that instead of agriculture representing 22\% of the economy in Central Africa, as it does in 2018, by 2040 it would have reduced to only 15\% in the Revolution in Agriculture scenario compared to a more rapid decline to $11 \%$ in the Current Path. On top of that the economy of Central Africa will be significantly larger than in the Current Path. Although the agricultural sector in Southern Africa shows the second least impressive growth in absolute size, the sector is already significantly smaller as a percent contribution to the total economy (at only seven percent in 2018), declining to six percent in the Revolution in Agriculture scenario instead of four percent in the Current Path. So instead of an agricultural sector that is valued at US\$71 billion in 2040 (the Current Path forecast) it would be US\$103 billion in size in the Revolution in Agriculture scenario.

These improvements are not given, however. Factors that could impact on the achievement of these changes include the utilisation of the water endowment available for irrigation, the effect of carbon fertilisation due to climate change on crop growth, as well as the possibility of new cultivars and genetically modified plants that are more temperature tolerant. ${ }^{44}$

The Agricultural Revolution could also-at least temporarily-reverse the long-term declining employment share in the agricultural sector. This would not only because farm labour will expand (since a larger sector is likely to

\footnotetext{
${ }^{44}$ Some of these constraints can be overcome through technology, such as the use of precision irrigation and application of precise amounts of fertiliser exactly where it is required. Then there is the potential of vertical farming that could produce $180 \mathrm{~m}$ tons of food globally, according to some.
} 
employ more people, even if that will be less workers per ton of output as productivity improves), but also because employment in up- and downstream from farming will increase as the size and sophistication of the agricultural sector expands. More than half of Africa's labour force is engaged in the agricultural sector with some estimates putting that portion much higher. But like in China, the agricultural sector in Africa is steadily losing its productive, working age population as young men and women migrate to cities in search of improved livelihoods.

A report on The Future of Work in Africa by the African Center for Economic Transformation in Ghana finds that boosting agricultural productivity may actually reduce the number of jobs in agriculture. ${ }^{45}$ However, they conclude that by lowering the costs of raw materials, jobs will be created downstream in the much larger agro-processing sector. Productivity improvements could come by upgrading value chain activities such as logistics, input services, storage and other off-farm activities-all of which will require improved connectivity and basic infrastructure. ${ }^{46}$

\section{The Contributions from Technology and Innovation}

When thinking about the future of agriculture (and the improvements modelled in the African Agricultural Revolution scenario) it is important to recognise the rapid improvements occurring in this sector and the extent to which agriculture is changing all over the world.

Countries such as Australia, the USA and some European nations, where large-scale industrial agriculture is well established, are experimenting with robotics to remove weeds and harvest crops. A fleet of small robots has even been tested to achieve tasks that were once the domain of large tractors, sprayers and planters. On high-intensity commercial farms remote-controlled spraying helicopters are already quite common.

Rather than replacing farm workers, of which there is an abundant supply on the African continent, agricultural technologies will likely help farmers to reduce inputs such as herbicides, pesticides and fertilisers through greater

${ }^{45}$ World Economic Forum, 2017. The Future of Jobs and Skills in Africa Preparing the Region for the Fourth Industrial Revolution. Geneva: World Economic Forum.

${ }^{46}$ Ibid., p. 4. 
precision in their use and application. And high technology devices like drones could help to inspect fields and monitor herd animals. ${ }^{47}$

While there is a general consensus that inefficient markets and lack of access to credit plague Africa's agricultural sector, the particular ways in which it affects farmers vary greatly. Even the World Bank recommends that 'researchers must locate the sources and causes of factor market failures more precisely'. ${ }^{48}$ For one, mobile technology can alleviate the bottlenecks in Africa's smallholder agricultural credit system and enable farmers to access farming inputs. Much of the reforms that could drive improved productivity are actually to be found in the way in which agricultural markets are structured at local level, but inputs are also important.

In Kenya, for example, the company FarmDrive ${ }^{49}$ uses mobile phones, alternative data and machine learning to unlock access to credit for smallholder farmers. FarmDrive does so firstly by collecting and aggregating various datasets, for instance from individual phone use, social media, agronomic, environmental, economic and satellite data, to produce a credit score for smallholder farmers.

The process involves many incremental steps such as first determining the exact location of the smallholder farm. ${ }^{50}$ Once the location is known on Google maps, it allows the system to access geospatial information that determines soil quality, weather conditions and market accessibility and then, using an algorithm, to determine a credit score. The best time, they found, to engage with farmers, is at 10 am (when cows are out grazing) and when they have their morning tea, switching their phones on for a short while. ${ }^{51}$

Secondly, FarmDrive offers a decision-making tool that enables financial institutions to develop small-scale agriculture loan products. In this way the company facilitates a process for smallholder farmers to access capital to purchase critical farming inputs such as seed, fertiliser and implements that could increase yields and revenues.

\footnotetext{
${ }^{47}$ Abboud, L., 2018. The Robot Revolution Down on the Farm. [Online] Available at: https://www.ft. com/content/5854088a-ddda-11e8-b173-ebef6ab1374a.

${ }^{48}$ The World Bank, n.d. Agriculture in Africa: Telling Facts from Myths. [Online] Available at: http:// www.worldbank.org/en/programs/africa-myths-and-facts.

${ }^{49}$ Kimani, R., and Bosire, P., 2019. FarmDrive. [Online] Available at: https://farmdrive.co.ke/.

${ }^{50}$ In most of rural Africa this is objectively unknown. FarmDrive resolves this challenge by determining location with reference to a known landmark. In rural Kenya, for example, the location of primary schools is objectively known, so the location of a farm is determined via a series of SMS questions such as time to walk to different primary schools. The more schools a farmer is familiar with in their area, the easier it is to hone into their specific location.

${ }^{51}$ Edwards, R., n.d. Finding Our Farmers; or, Shamba Iko Wapi? [Online] Available at: https://farmdr ive.co.ke/insights/3.
} 
In this manner, modern technology is opening up opportunities for smallholder farmers that would have been impossible a few years ago. The services provided by FarmDrive in Kenya benefits women in particular as they constitute the majority of smallholder farmers. FarmDrive has won a number of awards and gained substantial recognition as it rolls out its solution, one of many that are emerging in Africa for the continent's estimated 50 million smallholder farmers. It is part of an emerging trend across the continent to change a straightforward farming mindset to a modern, agribusiness mindset.

In Ghana, Kenya and Uganda more than 20,000 farms have access to simple and affordable smart insurance contracts (such as against crop failure or the loss of expensive breeding stock) via their smartphone, using blockchain technology. The system uses high-resolution satellite images to detect rainfall and plant growth data. ${ }^{52}$ Using digital platforms it is possible to connect smallholders directly to research and large packaging and distribution centres, to provide advice on what, when and where to plant, as well as weather forecasts. Companies such as AgroCenta in Ghana and Zenvus in Nigeria are all making a difference in this regard. ${ }^{53}$

The World Food Programme Rural Resilience Initiative (R4) is also helping to implement innovations in finance and insurance to reduce the risk of farming. Their efforts reached more than 57,000 farmers in Ethiopia, Senegal, Malawi, Zambia and Kenya in 2018. This has increased food and income security by managing climate-related risks. ${ }^{54}$ Remote sensing from drones can monitor soil moisture content and help to make irrigation systems more efficient. In addition, over the last decade the Alliance for a Green Revolution in Africa (AGRA) has invested hundreds of millions of dollars in improved seeds and has doubled maize yields in the 18 countries where they work. ${ }^{55}$

According to the Food and Agriculture Organization currently one-third of the world's food, approximately 1.3 billion tons worth US $\$ 1.2$ trillion a year is wasted. In sub-Saharan Africa this mostly occurs in the distribution process

\footnotetext{
52Bird, J., 2018. 'Smart' Insurance Helps Poor Farmers to Cut Risk. [Online] Available at: https://www. ft.com/content/3a8c7746-d886-11e8-aa22-36538487e3d0.

${ }^{53}$ AgroCenta. [Online] Available at: https://agrocenta.com/ and Zenvus. [Online] Available at: https:// www.zenvus.com/.

54World Food Programme \& Oxfam America, 2011. The R4 Rural Resilience Initiative. [Online] Available at: https://www1.wfp.org/r4-rural-resilience-initiative.

${ }^{55}$ Gebre, S., 2016. AGRA Plans to Invest $\$ 500$ Million in African Seed Companies. [Online] Available at: https://www.bloomberg.com/news/articles/2016-09-07/agra-plans-to-invest-500-million-in-afr ican-seed-companies.
} 
from production to retailing. In rich countries food is generally thrown away by the consumer. ${ }^{56}$

By using modern technology it is now possible to reduce losses significantly by tracking inventory and reducing food waste along the distribution chain from farm-gate to the domestic retailer or the export market. One example is InspiraFarms that produces affordable, energy-efficient cold storage and processing equipment for on or off-grid use. ${ }^{57}$

Low internet penetration rates and electricity access in rural areas in Africa are the biggest obstacles to applying modern technology in agriculture. Both challenges can be overcome by using renewables and the various innovations discussed in Chapter 10.

\section{Conclusion: Aiming at Food Security and Growth}

Without food security, developing countries cannot escape from hunger, poverty and the variances of nature. Without food security meaningful advancement is difficult, if not impossible, to sustain and it is increasingly evident that the effects of climate change are likely to hold significant negative consequences for agriculture in much of Africa (see Chapter 15).

Because of the way in which colonialism shaped and then locked Africa's agricultural sector into the global economy, and subsequent insufficient, poorly designed and inefficient government support for agriculture, Africa has not been able to benefit from this key sector. Yet the continent has a huge potential and it is agriculture upon which the largest portion of Africans depend for survival. Subsistence and smallholder agriculture that largely caters for household consumption needs targeted and coordinated support from government which is quite different from the private-sectorled growth model of medium and large-scale commercial farming, although that too has its place. Actually clumsy interventions by African governments to set minimum prices for commodities such as cocoa, coffee and cashew nuts without much wider consideration of the impact often have unintended consequences. For example it could encourage an increase in production by many more poor farmers, causing the price of the commodity to fall. The result is to trap more poor people in subsistence farming from which they are unable to escape. In fact low and even most lower-middle-income African

\footnotetext{
${ }^{56}$ Food and Agriculture Organization, n.d. Key Facts on Food Loss and Waste You Should Know! [Online] Available at: http://www.fao.org/save-food/resources/keyfindings/en/.

${ }^{57}$ InspiraFarms. [Online] Available at: http://www.inspirafarms.com/about-us/?lang=za.
} 
countries should probably place an emphasis on food self-sufficiency rather than exports.

There have been some progress but World Bank president Robert McNamara's prognosis in Nairobi in 1973 that 'there can be no long-term solution to the food problem' 58 without rapid progress in smallholder agriculture remains valid today in much of Africa.

For a successful agricultural transition and to expand local agricultural markets it is especially important to focus on indigenous crops, such as cassava, cowpea, soybean and yam, as well as indigenous practices before looking elsewhere. ${ }^{59}$ Once that is achieved, steady progress up the agroprocessing value chain will unlock improvements elsewhere rather than efforts to enter the global food export market without sufficient domestic reform.

Much is changing in Africa. The Indorama Eleme public-private fertiliser plant that was completed in 2016 and that will shortly double its capacity helped to turn Nigeria from a large fertiliser importer to a self-sufficient producer and now to a net exporter. ${ }^{60}$ In addition, Morocco's OCP Group, which holds $75 \%$ of the world's phosphate reserves (a key ingredient for phosphate-based fertilisers), has announced its own plans for a US\$1 billion industrial investment in fertiliser plants in Nigeria while construction of its massive plant in Dire Dawa in Eastern Ethiopia (at a cost of US\$3.7 billion) has started. ${ }^{61}$ Across Africa, from Angola to Kenya, governments and the private sector are investing in the key enablers of agricultural growth. But much more is required, particularly in incorporating resilience and adaptation to climate change into Africa's Revolution in Agriculture.

Prosperity requires that a country move up the agricultural value chain and avoid being suckered by corporate social responsibility programmes that promise to tinker with the worst effects of colonial-style production, but that does not structurally intervene to promote food self-sufficiency and shifting value addition to Africa. The attraction often sold to Africans is to use its

\footnotetext{
${ }^{58}$ McNamara, R., 1973. Address to the Board of Governors by Robert S. McNamara Presidential speech. Washington, DC: World Bank.

${ }^{59}$ The International Institute of Tropical Agriculture (IITA). [Online] Available at: https://www.iita. org/ does particularly impressive work in this regard.

${ }^{60}$ African Development Bank Group, 2019. Nigeria: Fertilizer Project Raises Yields by Over 50\%, Showcases Successful PPPS, 21 January 2019. https://www.afdb.org/en/news-and-events/nigeria-fertil izer-project-raises-yields-by-over-50-showcases-successful-ppps-18933.

${ }^{61}$ Bazza, T. 2019. Morocco's OCP to Build 2 Fertilizer Plants in Nigeria. Morocco World News, 17 January 2019. https://www.moroccoworldnews.com/2019/01/263594/morocco-ocp-fertilizer-pla nts-nigeria/; 2m Editor, 2019. Ethiopia’s New Fertilizer Plant to Help Fulfill Local Demands: Ministry of Agriculture, 8 July 2019. 2Merkato.com. https://www.2merkato.com/news/alerts/5736-ethiopia-snew-fertilizer-plant-to-help-fulfill-local-demands-ministry-of-agriculture.
} 
leverage in products such as cocoa and coffee to improve their share of valueadd in these massive markets. But in the absence of effective agricultural management and producer associations with the muscle to manage the sector it is probably more important to diversify the agricultural products in countries such as Ghana and Côte d'Ivoire than trying to develop a cocoa cartel. And then there is the challenge that for much of Africa's young population the idea of turning to agriculture as a source of livelihood is a strong association with poverty. Changing that mindset will be difficult since the sector suffers from poor infrastructure, insecure property rights, lack of access to credit, no or limited provision of electricity and lack of access to modern technologies. All of these hurdles can be overcome but it requires a host of interventions including challenging current practices of tenure insecurity, unlocking access to credit, using high-yielding seed varieties and modern inputs such as fertilisers, pesticides and eventually introducing agricultural machinery to emulate some of the positive aspects of the so-called Green Revolution in South Asia and South America during the 1950s and 1960s.

An African Agricultural Revolution could potentially have a major impact, ranging from reduced stunting among children and undernourishment among adults to increased incomes and a reduction in poverty. Most importantly, the continent would become less dependent on food imports with huge attendant advantages. Food self-sufficiency can play an important role to reduce poverty, which is the subject of the next chapter.

\section{Further Reading}

AGRA. 2018. Africa Agriculture Status Report: Catalyzing Government Capacity to Drive Agricultural Transformation (Issue 6). Nairobi, Kenya: Alliance for a Green Revolution in Africa (AGRA).

FAO, The role of agriculture and rural development in achieving SDG 1.1 February 22, 2019, Paper for presentation at the United Nations Expert Group Meeting on Eradicating Rural Poverty to Implement the 2030 Agenda for Sustainable Development, 27 February to 1 March 2019, UNECACCAA, available at https://www.un.org/development/desa/dspd/wp-content/upl oads/sites/22/2019/03/FAO-ending-extreme-rural-poverty-1.pdf. Accessed on 25 December 2019.

Jane Nelson No Smallholder Farmer Left Behind, chapter 4 in Homi Kharas, John W. McArthur, and Izumi Ohno (eds.). 2019, October 29. Leave No One Behind: Time for Specifics on the Sustainable Development Goals. Brookings. 
Open Access This chapter is licensed under the terms of the Creative Commons Attribution 4.0 International License (http://creativecommons.org/licenses/by/4.0/), which permits use, sharing, adaptation, distribution and reproduction in any medium or format, as long as you give appropriate credit to the original author(s) and the source, provide a link to the Creative Commons license and indicate if changes were made.

The images or other third party material in this chapter are included in the chapter's Creative Commons license, unless indicated otherwise in a credit line to the material. If material is not included in the chapter's Creative Commons license and your intended use is not permitted by statutory regulation or exceeds the permitted use, you will need to obtain permission directly from the copyright holder.

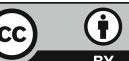

